\title{
Lander techniques for deep-ocean biological research
}

\author{
PM BAGLEY, IG PRIEDE, AD JAMIESON, DM BAILEY, EJV BATTLE, G HENRIQUES \\ and KM KEMP \\ Oceanlab, University of Aberdeen, Neweburgh, Aberdeenshire, Scotland, UK
}

\section{Abstract}

Photographic landers have proved to be a useful tool for deep-ocean biological research. This paper presents a calculation to define the niche landers have when compared to wire gears used on research vessels, and then describes how landers have developed to enable experiments previously only possible in shallow water or in the laboratory to be transported to the deep ocean at depths to $6000 \mathrm{~m}$. A number of diverse case studies using the authors' landers are described to illustrate these developments. These studies include fish tracking experiments using the AUDOS (Aberdeen University Deep Ocean Submersible) Lander to study deep-ocean fish movements. Two experiments designed to investigate deep-ocean fish physiology are presented; the first investigated muscle performance of fish in-situ using an electrical stimulator aboard the 'Sprint' Lander; and the second describes a lander capable of trapping and measuring the in-situ oxygen consumption of deep-ocean fish. A further case study to investigate bioluminescence in both the water column and on the sea floor to abyssal depths using the ISIT (Intensified Silicon Intensified Tube) lander is described. Finally, to investigate the effects of time signals on deep-ocean animals a case study using the DOBO (Deep Ocean Benthic Observer) lander is detailed.

\section{Introduction}

The oceanic and atmospheric sciences have been revolutionised in recent decades by the use of satellites in Earth orbit as instrument platforms that continuously scan large areas of the Earth surface. In particular, marine sciences have benefited greatly from the ability to visualise oceanic fronts, gyres and areas of primary production.' For scientific studies beneath the surface, however, in-situ instruments are the only way to make observations. Whilst low frequency echosounders and sonars can map the sea floor at abyssal depths, high-resolution studies require a towed body close to the sea floor. For any other measurement or observation (physical, chemical, biological) on the deep-ocean floor the presence of a man-made instrument is required.

In deep-ocean biology, trawl sampling has greatly enhanced our understanding." However, animals brought to the surface are almost inevitably killed due to pressure and temperature change, hence our knowledge of deep-ocean life, until the advent of in-situ techniques, was restricted to the study of dead animals. Modern in-situ techniques such as manned submersibles or Remotely Operated Vehicles (ROVs) have further extended the boundaries of knowledge; however the requirement for the constant presence of a surface vessel precludes them from long-term studies. ${ }^{3}$

Autonomous Underwater Vehicles (AUVs) show great promise for the future of in-situ marine research. However, sampling limitations due to limited dynamic payload capability, and finite mission duration restricts their use for biological research. Particularly in decpsea research, landers are perceived as an important means of obtaining data that could not be achieved in any other way. They can be left to work autonomously for periods of hours to years and, unlike manned submersibles, ROVs, and other wire gears, they can operate whilst the ship is back in port. Indeed, it is possible for a single ship to service a fleet of landers operating over a wide area of the sea floor. ${ }^{5}$ Landers also provide a means for small research vessels without winches big enough to carry cable capable of reaching the abyssal sea floor to recover information from the deep-sea.

\section{Lander technology}

\section{Lander definition}

The term 'lander' refers to a subsea mooring that descends to the sea floor, carries out a series of tasks autonomously for periods of days to years storing data on board, and then ascends to the surface at the end of the mission for recovery by a surface ship. A typical lander comprises a chassis, buoyancy module, rccovery module and ballast with release mechanism. Depending on the size of the lander one or more scientific payloads can be attached for monitoring processes in the surface layers of the sediment and the bottom water.

The lander is usually ballasted to be negatively buoyant so that it descends to the sea floor at a rate of $0.5-1.0 \mathrm{~m} / \mathrm{s}^{-1}$, which gives a relatively soft landing so as to reduce sediment disturbance. At the end of the mission ballast weights are shed either by time release or acoustic command from the surface. The lander then ascends because of positive buoyancy to be recovercd by the surface ship. A recovery module is usually equipped with radio beacons, strobe lights and visual markers to aid location. Landers have evolved from 
conventional occanographic instrument moorings such as current meter or sediment trap arrays but are charactcrised by an instrument package standing or suspended close to the sea floor.

\section{Lander niche as a tool for marine research}

If experiments on the sea floor have durations of months or years it is immediately obvious that an autonomous platform should be placed on the sea floor. However, experiments of a few hours duration might be carried out either by suspending an instrument on a vertical cable (eg, CTD, ROV) or by autonomous lander. For conventional wire work the total ship time $\left(T_{S}\right)$ required is:

$$
T_{s}=T_{t}+T_{d}+T_{b}+T_{a}
$$

where $T_{t}=$ ship transit time

$\mathrm{T}_{\mathrm{d}}=$ gear descent time

$\Gamma_{\mathrm{b}}=$ gear bottom time

$\mathrm{T}_{\mathrm{a}}=$ gear ascent time.

However, for lander work the ship does not have to remain on station after deployment (no bottom time, $\mathrm{T}_{\mathrm{b}}$ ), but there is additional time required to locate the lander and time required to recover it from the surface. Therefore, for lander work:

Ship time required $T_{s}=T_{t}+T_{d}+T_{c}+T_{a}+T_{r}$

where, $T_{C}=$ time required to establish acoustic contact and activate release

$\mathrm{T}_{\mathrm{r}}=$ lander recovery time after surfacing.

Table 1 illustrates a simple example to compare wire and lander work for an experiment lasting $10 \mathrm{~h}$ on the sca floor:

Fig 1 shows the results of this analysis giving the ratio of bottom time over ship time for depths from $100 \mathrm{~m}$ to $6000 \mathrm{~m}$. Obviously, the bottom time using the

\begin{tabular}{|c|c|c|c|}
\hline \multicolumn{2}{|l|}{ Wire Work } & \multicolumn{2}{|l|}{ Lander Work } \\
\hline Transit time $\left(T_{1}\right)$ & $4 \mathrm{~h}$ & Transit time $(T)$ & $4 \mathrm{~h}$ \\
\hline Descent rate $\left(T_{d}\right)$ & $3600 \mathrm{~m} \bullet \mathrm{h}^{-1}$ & Descent rate $\left(T_{d}\right)$ & $2400 \mathrm{~m} \bullet \mathrm{h}^{-1}$ \\
\hline Bottom time $\left(T_{b}\right)$ & $10 \mathrm{~h}$ & Bottom time $\left(T_{n}\right)$ & (10h) \\
\hline Ascent rate $\left(\pi_{a}\right)$ & $3600 \mathrm{~m} \bullet \mathrm{h}^{-1}$ & $\begin{array}{l}\text { Search time }\left(T_{d}\right) \\
\text { Ascent rate }\left(T_{a}\right) \\
\text { Recovery time }\left(T_{t}\right)\end{array}$ & $\begin{array}{l}0.5 h \\
2400 m \cdot h^{11} \\
0.5 h\end{array}$ \\
\hline
\end{tabular}

Table 1: Parameters for a typical 10h experiment with 40 nmiles steaming time between stations

Fig 2: Ratio of ship time achieved by landers compared to wire gear for experiments of different durations but otherwise characterised by data in Table 2 . Values greater than $R=1$ indicate that landers use ship time more efficiently than wire gears

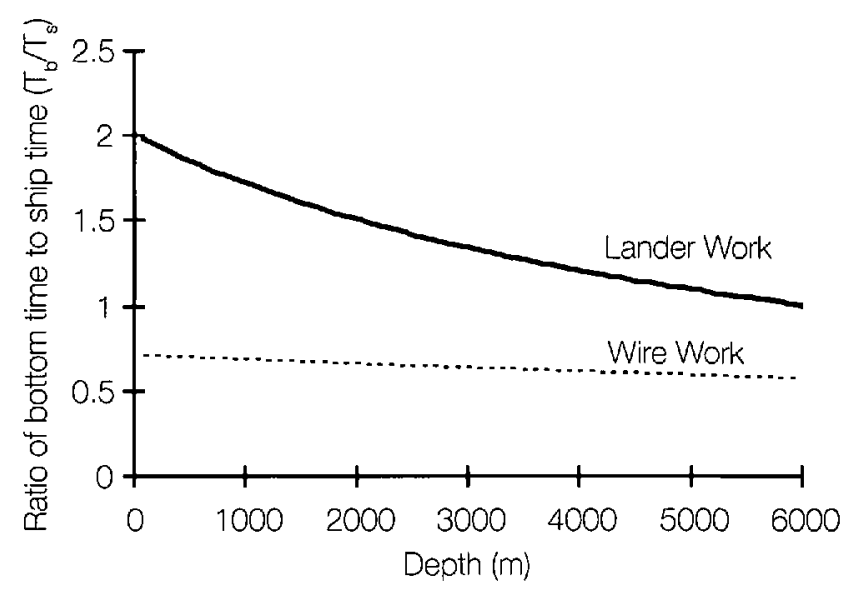

Fig 1: Comparison of bottom time (useful working time) per hour of ship time using landers and wire gear for an experiment of $10 \mathrm{~h}$ duration. Analysis assumes the ship has other useful work to do during lander bottom time

wire is always less than the ship time. However, landers achieve about twice as much work as conventional wire gears. This analysis assumes that more than one lander is available or the ship has other useful work to do in the time between deployment and recovery. It is notable that although landers are associated with deep-sca research, they are most advantageous in shallow waters. However, the increased probability in shelf areas of landers being damaged by shipping or fishing activity has to be offset against this apparent advantage.

To determine at what point a lander becomes more efficient than a wire gear, this analysis can be extended to compare landers and wire gears for experiments that have different bottom time durations. If:

$$
\mathrm{R}=\frac{\begin{array}{l}
\text { Ship time required } \\
\text { for wire gear }
\end{array}}{\begin{array}{l}
\text { Ship time required } \\
\text { for lander }
\end{array}}=\frac{\left(\mathrm{T}_{\mathrm{t}}+\mathrm{T}_{\mathrm{d}}+\mathrm{T}_{\mathrm{b}}+\mathrm{T}_{\mathrm{a}}\right) \text { Wire gear }}{\left(\mathrm{T}_{\mathrm{t}}+\mathrm{T}_{\mathrm{d}}+\mathrm{T}_{\mathrm{c}}+\mathrm{T}_{\mathrm{a}}+\mathrm{T}_{\mathrm{r}}\right) \text { Lander }}
$$

Fig 2 shows the results of this analysis, giving a set of curves for $\mathrm{R}$ for experiments of bottom time duration from $0.5 \mathrm{~h}$ to $10 \mathrm{~h}$. At $2 \mathrm{~h}$ duration the performance of the two systems are approximately equal $(R=1)$. At $4 \mathrm{~h}$ duration the lander system has advantages, although

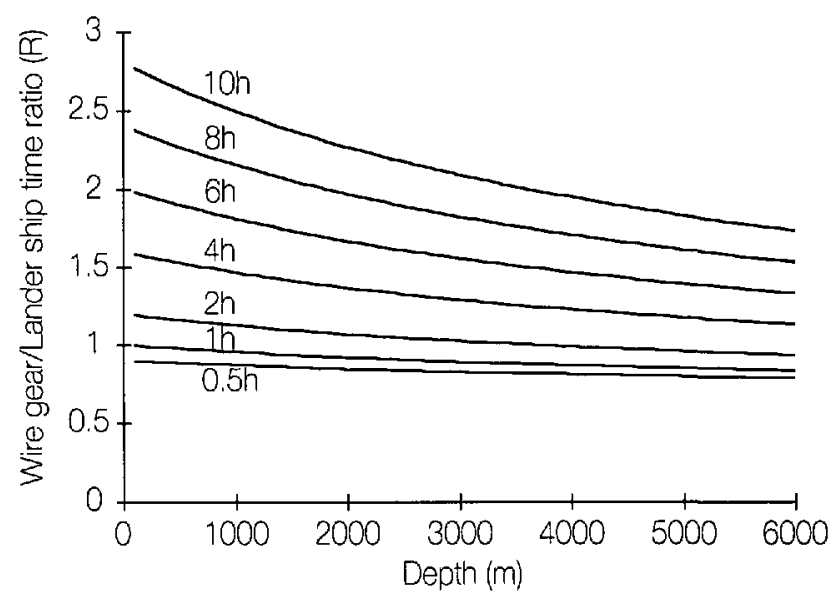




\begin{tabular}{|l|l|l|l|}
\hline Acronym & Name & Institute & Measurement \\
\hline MAP I/I & Module Autonome Pluridisciplinaire & IFREMER, France & Benthic boundary layer flow \\
\hline RAP $\|$ & Respirometre & IFREMER, France & Benthic chamber sediment oxygen consumption \\
\hline FFR & Free- Fall Respirometer & GEOMAR, Germany & Benthic chamber sediment oxygen consumption \\
\hline Goteborg & Goteborg chamber and profile lander & Goteborg, Sweden & $\begin{array}{l}\text { Benthic chamber sediment oxygen consumption, } \\
\text { solute fluxes }\end{array}$ \\
\hline IMBC & Compact respirometer lander & IMBC, Crete & Benthic chamber sediment oxygen consumption \\
\hline AUDOS & $\begin{array}{l}\text { Aberdeen University } \\
\text { Deep Ocean Submersible }\end{array}$ & Aberdeen, Scotland & $\begin{array}{l}\text { 2D Acoustic tracking of fish ingesting } \\
\text { transponder tags }\end{array}$ \\
\hline ATTIS 1 & $\begin{array}{l}\text { Acoustic Telemetry and Transponder } \\
\text { Interrogation System \#1 }\end{array}$ & Aberdeen, Scotland & $\begin{array}{l}\text { 1D Acoustic tracking of fish ingesting } \\
\text { transponder tags }\end{array}$ \\
\hline ATTIS 2 & $\begin{array}{l}\text { Acoustic Telemetry and Transponder } \\
\text { Interrogation System \#2 }\end{array}$ & Aberdeen, Scotland & $\begin{array}{l}\text { 1D Acoustic tracking of fish ingesting } \\
\text { transponder tags }\end{array}$ \\
\hline ATTIS 3 & $\begin{array}{l}\text { Acoustic Telemetry and Transponder } \\
\text { Interrogation System \#3 }\end{array}$ & Aberdeen, Scotland & $\begin{array}{l}\text { 1D Acoustic tracking of fish ingesting } \\
\text { transponder tags }\end{array}$ \\
\hline ATTIS 4 & $\begin{array}{l}\text { Acoustic Telemetry and Transponder } \\
\text { Interrogation System \#4 }\end{array}$ & Aberdeen, Scotland & $\begin{array}{l}\text { 1D Acoustic tracking of fish ingesting } \\
\text { transponder tags }\end{array}$ \\
\hline LAFF V/II & Large Abyssal Food Fall & Aberdeen, Scotland & Large carcass consumption rates on the sea floor \\
\hline ISIT & Intensified Silicon Intensified & Aberdeen, Scotland & $\begin{array}{l}\text { Bioluminescence monitoring of the benthic } \\
\text { boundary layer }\end{array}$ \\
\hline Fish Trap & Babe Lander & Aberdeen, Scotland & Capture of deep-sea fishes \\
\hline SPI & Sediment Profile Imagery & Galway, Ireland & Sediment profiling imagery (wire gear) \\
\hline CTD & Conductivity, Temperature, Depth & SOC, England & Conductivity, Temperature, Depth (wire gear) \\
\hline Multicore & Multicore & SOC, England & Sediment cores (wire gear) \\
\hline
\end{tabular}

Table 2: Landers and other gears operated during the ALIPOR cruise D222 (leg A)

these have to be traded off against the requirement for a second lander (so the ship has other work to perform while the first lander is operating on the sea floor), and the possible risk of loss of the lander. For experiments having a bottom time lasting longer than $8 \mathrm{~h}$, autonomous landers emerge as the most efficient use of ship time $(\mathrm{R} \geq 2)$.

\section{Practical experience: The ALIPOR cruises}

ALIPOR (Autonomous Lander Instrument Packages for Oceanographic Research) was a EU MAST III (Marine Science and Technology) programme GT 950010 coordinated by the University of Aberdeen involving nine partners in six EU countries. It is recognised that to carry out large-scale research in the deepsea, the resources of single institutions and countries are likely to be insufficient. A number of groups throughout Europe have developed deep-sea lander technologies and it is important that these systems should be able to work together in joint programmes and also avoid mutual interference. The aim of the ALIPOR programme was to create a compatible European fleet of lander vehicles and to gain experience of operation of fleets of landers from one or more ships.

As part of the ALIPOR programme, research cruises were undertaken at locations around the Porcupine Seabight $\left(40^{\circ} 30^{\prime} \mathrm{N} ; 1^{\circ} 00^{\prime} \mathrm{W}\right)$ and Porcupine Abyssal Plain $\left(48^{\circ} 50^{\prime} \mathrm{N} ; 16^{\circ} 30^{\prime} \mathrm{W}\right)$ areas of the north-east
Atlantic Ocean. During these cruises landers from each institution were operated in cooperation to increase the knowledge of deep-sea ocean processes. Tablc 2 summaries the type of landers and other gears used during the ALIPOR cruise D222 (leg A). ${ }^{6}$

These cruises were scheduled to maximise the amount of bottom experimentation time within the available weather and logistics windows. This was achieved by deploying multiple landers so that experimentation was in progress on the sea floor even if the ship was hove to because of bad weather. The ship used for both cruises was the RRS Discovery, a conventional ship with bow thruster, but no dynamic positioning.

The ship was in the working area for just over 26 days $(634.7 \mathrm{~h})$. She steamed between three main working areas (Porcupine Abyssal Plain 48 $50^{\prime} \mathrm{N} ; 16^{\circ} 30^{\prime} \mathrm{W}$, OMEX site $49^{\circ} 11^{\prime} \mathrm{N}$; $12^{\circ} 49^{\prime} \mathrm{N}$, BIOTRANS $47^{\circ} 40^{\prime} \mathrm{N}$; $19^{\circ} 50^{\prime} \mathrm{W}$ ). During this time 40 lander deployment and recovery operations were carried out which is equivalent to one lander operation every $7.9 \mathrm{~h}$. Fig 3 shows the deployment time for each lander used on the cruise. There were also three wire gears (SPI, CTD, and multicorer) that are shown at the bottom of the figurc. For most of the cruise at least four landers were deployed simultaneously, and for periods, all 11 landers were operating on the sea floor simultaneously. The total amount of subsea time achieved during the course of the cruise was $3804.6 \mathrm{~h}$, or almost six times (an efficiency of $599 \%$ ) the ship time expended. 


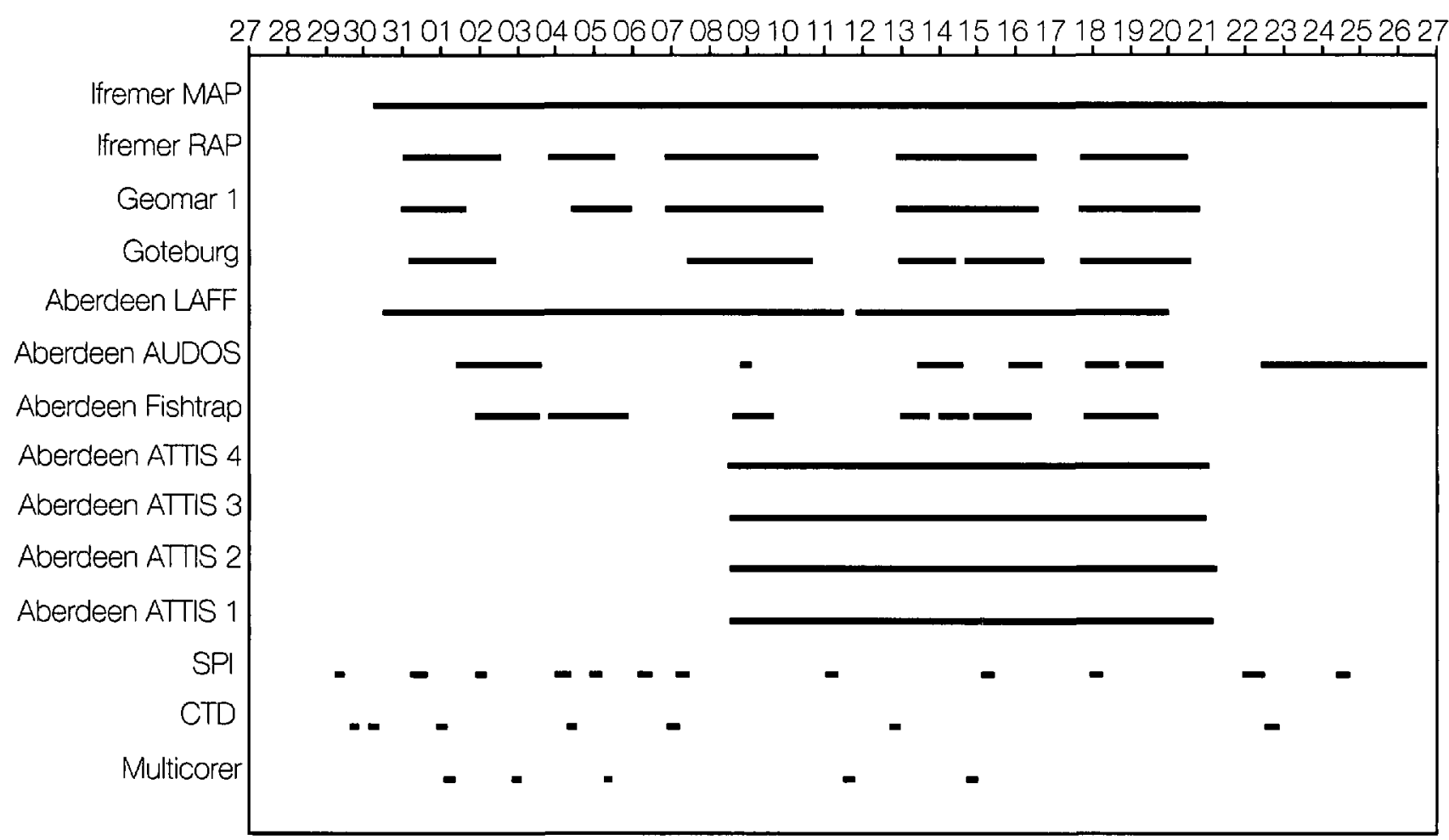

Cruise duration 634.7h; Total lander deployment duration 3804.6h; Efficiency 599\%

Fig 3: Time bar chart for the ALIPOR research cruise 222A (1996). Bar lines represent lander and wire gear deployment durations over the course of the cruise. Wire gears were SPI, CTD, and Multicore; all other gears were landers

Once the lander had surfaced, the average time required to locate it, manoeuvre the ship alongside and successfully grapple it was $22 \mathrm{~min}$. Bringing it onboard and securing it so that the ship could get underway took $14 \mathrm{~min}$. Thus the average total recovery time was 36 min once the lander surfaced.

\section{In-situ lander deep-ocean biological research: Case studies}

A photographic lander is perhaps the simplest form of deep-ocean lander and continues to prove of great value in studying the remote deep-sea environment. ${ }^{7}$ To show how the lander technique can be used to transport experiments, previously only available to terrestrial and shallow-water biologists, to the deep ocean, a number of case studies are described illustrating diverse experiments carried out by the authors.

\section{The AUDOS fish tracking lander}

One of the great challenges of oceanography is to understand how agents such as current, waves and marine organisms transport matter across the sea floor. The AUDOS (Aberdeen University Deep Ocean Submersible) lander was designed to address the smallscale transport of matter by marine organisms by tracking the movements of deep-sea fish at abyssal depths. Fishes can play a role in the transport of organic mat- ter by virtue of consumption and dispersal of food material across the sea floor.

Miniature acoustic and radiolocation tags have been used for many years for the study of fish behaviour. Tags (pingers) attached internally or externally transmit a short acoustic pulse at a pre-defined repetition rate. Mitson \& Storton-West ${ }^{8}$ enhanced this technique, tracking plaice (Pleuronectes platessa) using a $300 \mathrm{kHz}$ transponder tag. The tag, when interrogated by a shipborne sidescan sonar, appeared as a bright spot on a sonar display. However, only one transponder could be tracked at any time, and the whole resources of the surface ship were used to follow one fish.

Using the AUDOS fish tracking lander as the delivery system Bagley ${ }^{9,10}$ developed a Code Activated Transponder (CAT) that required a unique interrogation code before a deployed CAT would respond. The CAT was designed to operate at depths to $6000 \mathrm{~m}$ from a sonar deployed on the AUDOS lander operating on the sea floor." Potentially 32 fish could be tracked simultaneously.

Once on the sea floor fish were attracted to AUDOS by bait attached below the vehicle, in view of a camera. Some of the bait was used to make up small bait parcels containing the CAT, which the fish ingested. As the fish (with CAT tags in their stomachs) moved away from AUDOS the sonar aboard AUDOS tracked their movements to a nominal radius of $800 \mathrm{~m}$. The CATs 

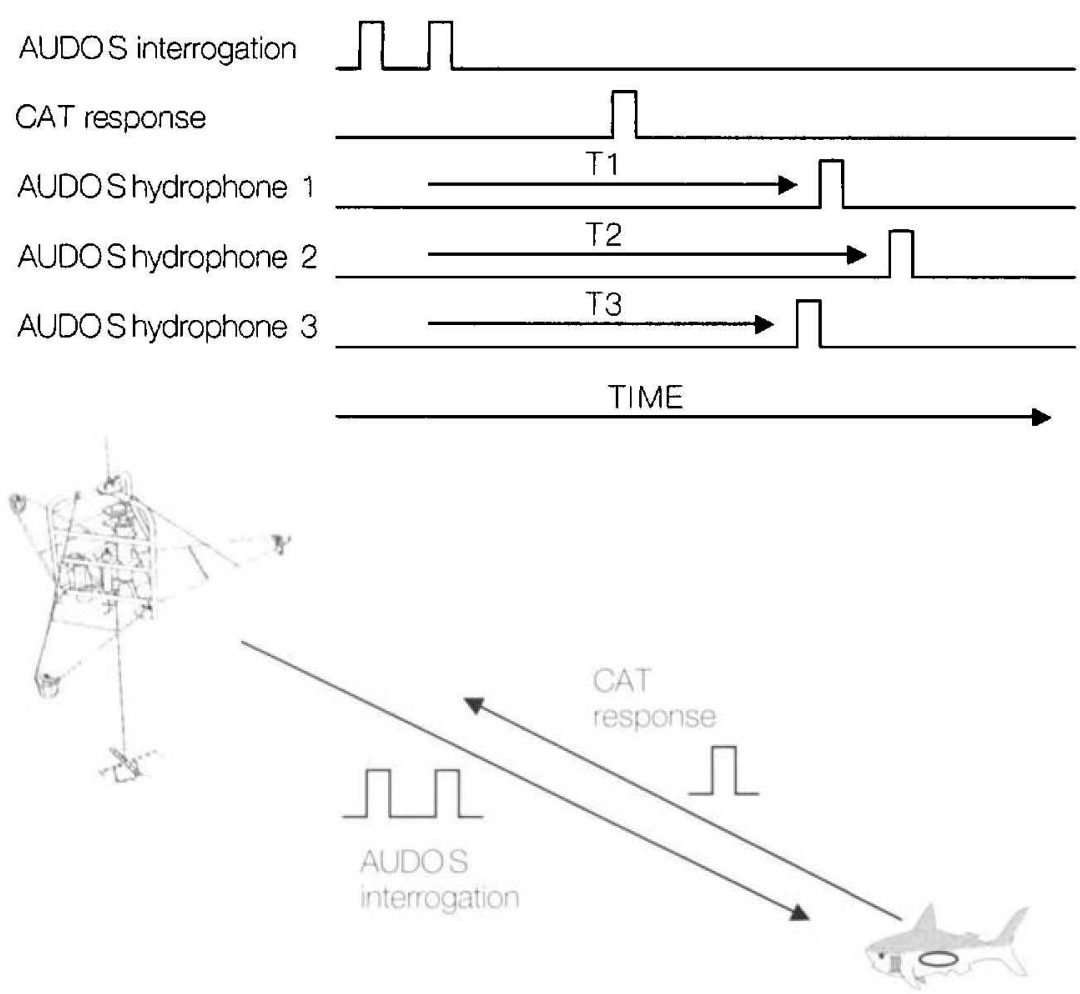

Fig 4: The AUDOS fish tracking lander operation. Differences in periods $\mathrm{T} 1, \mathrm{~T} 2, \& \mathrm{~T} 3$ are exaggerated to show how the CAT response is detected at slightly different times at each of the AUDOS hydrophones

were miniature $(67 \mathrm{~mm}$ long, $16 \mathrm{~mm}$ wide) acoustic transponders that only responded to a unique dual $77 \mathrm{kHz}$ pulse position interrogation code generated by the AUDOS sonar. If the time separation between the two pulses was the same as the time spacing pre-programmed into the CAT during manufacture, the CAT responded with its own $5 \mathrm{~ms}$ duration $77 \mathrm{kHz}$ pulse. The CAT response was detected back at AUDOS by three equally spaced hydrophones. The arrival time of the CAT response at each of the hydrophones depended upon the distance between the CAT and each hydrophone. Therefore, by accurately timing the period from interrogation to the detection of a response from the CAT at each hydrophone (T1, T2, \& T3), the location (in two dimensions) of the CAT could be calculated by triangulation (Fig 4).

Fig 5 shows a typical track of a deep-ocean demersal fish (Coryphaenoides armatus) at $4800 \mathrm{~m}$ in the Porcupine Abyssal Plain area of the north-east Atlantic Ocean.

\section{The 'Sprint' lander}

In-situ studies of whole fish and in vitro experiments with metabolic enzymes suggest that the metabolic rates of deep-sea fish are lower than those of related shallowwater species at similar temperatures. Measuring faststart performance provides a non-invasive but quantitative measure of maximum activity capacity and may indicate the relative importance of burst performance to animals. ${ }^{12}$ The 'Sprint' lander (Fig 6) was used to deliver an animal stimulation experiment to the deepsea floor. Animals were attracted to bait such that they were in view of a high-speed camera, and between two electrodes situated $1 \mathrm{~m}$ apart. At timed intervals a short

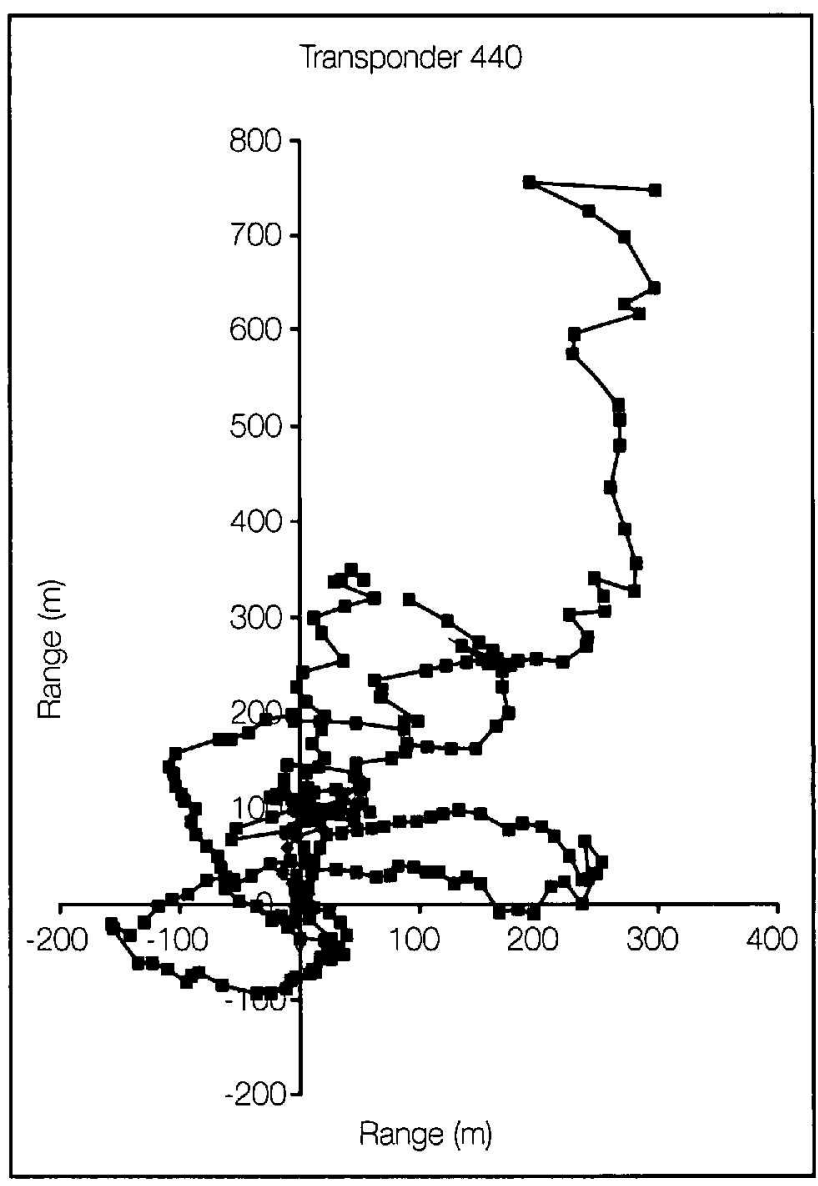

Fig 5: Typical Code Activated Transponder track of a demersal fish (Coryphaenoides armatus) at $4800 \mathrm{~m}$ depth in the Porcupine Abyssal Plain, north-east Atlantic Ocean. The AUDOS lander with onboard sonar is located at the origin 


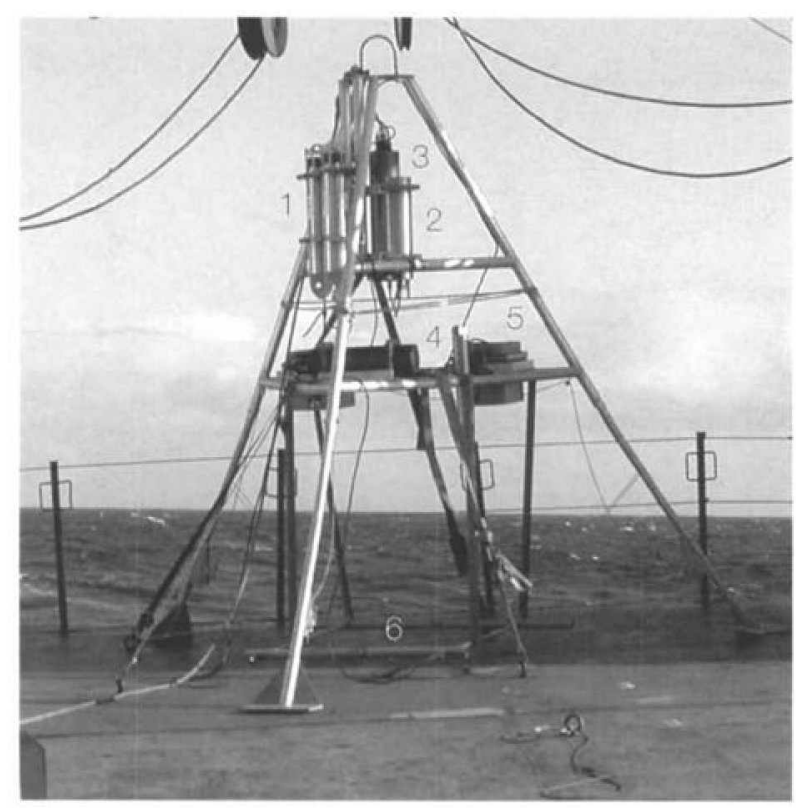

pulsc clectric field gencrated between the two electrodes stimulated animals at the bait to perform a fast start, escape response. Off-line analysis of the high-speed video on rccovery of the lander enabled muscle performance to be measured.

Although, clectric fishing and electrical stimulation of fish muscle was well founded in terrestrial studies ${ }^{13,14}$ little was known of the levels of electrical stimulation required to stimulate deep-ocean animal fast start responsc. Although estimates from previous studies ${ }^{15,16}$ wcre made, flexibility in levels of electrical stimulation was requircd. Therefore, an electric stimulator was designcd that was capable of generating a finite range of voltages $(16,21,26,31,36,40,47$, and $57 \mathrm{~V})$, at a programmable variable pulse width. Typically, an electrode array immersed in seawater can result in a resistance of approximately $0.1 \Omega$. Therefore, the electrical stimulator must be capable of generating instantaneous currents in excess of $570 \mathrm{~A}$ for the $57 \mathrm{~V}$ amplitude setting. This was achicved using a bandgap referenced programmable power supply trickle charging a capacitive array $(0.198$ F). Once charged, under microprocessor control the capacitors were discharged through the clcctrodc array via a high power IGBT transistor stage. Pulse width was controlled under software by utilising the microprocessor's pulse width modulation output.

Successful fast start response was achieved with the fish Antimora rostrata at $2500 \mathrm{~m}$ in the Porcupine Seabight arca of the north-east Atlantic with a stimulation pulse of $40 \mathrm{~V}$ for $2 \mathrm{~ms}$. A. rostrata with peak velocity of $0.7 \mathrm{~ms}^{-1}$ and white muscle output power of $17.0 \mathrm{~W} \mathrm{~kg}^{-1}$ has performancc similar to shallow-water fish at the same tempcrature. $^{12}$

Fig 7: Modes of operation of the ISIT Lander; (a) Bathypelagic: ISIT lander free-falls through the water column recording bioluminescent occurrences; (b) Sea floor: ISIT lander records spontaneous bioluminescent events occurring at bait
Fig 6: The 'Sprint' Lander. (1) Acoustic releases, (2) High speed camera, (3) Controller, (4) Electric stimulator, (5) Battery, (6) Electrode array

\section{The ISIT lander}

Sunlight is an important factor in the morphology and bchaviour of animals in the top $1000 \mathrm{~m}$ of the ocean. However, deeper than $1000 \mathrm{~m}$ no sunlight penetrates and yet the majority of animals including fishes still have operational eyes and well developed visual centres in the brain." The only source of light at such depths is of biological origin. Many marine animals are capable of producing light or maintain a population of luminescent bacteria. ${ }^{18}$ The eyes of deep-sea animals are clearly advantageous in detecting such biological light sources either from the same or different species. Bioluminescence has been extensively investigated in the surface layers of the ocean but little is known about the frequency and function of bioluminescence at depths greater than $1000 \mathrm{~m}$, either in mid-water (bathypelagic) or on the decp-sca floor at bathyal and abyssal depths.

Experiments were designed to investigatc the sources of light likely to be seen by deep-sea fishes and other animals whose eyes are often adapted to detect targets of very low intensity below the threshold of human vision. An ISIT (Intensified Silicon Intensificd Target) camera (Konsberg-Simrad) provided a suitable detector with sensitivity corresponding approximately to that of many deep-sea animal eyes. For bathypclagic studies the ISIT camera was fixed downward facing and focused on a mesh screen at $0.5 \mathrm{~m}$ distance (Fig $7 \mathrm{a}$ ).

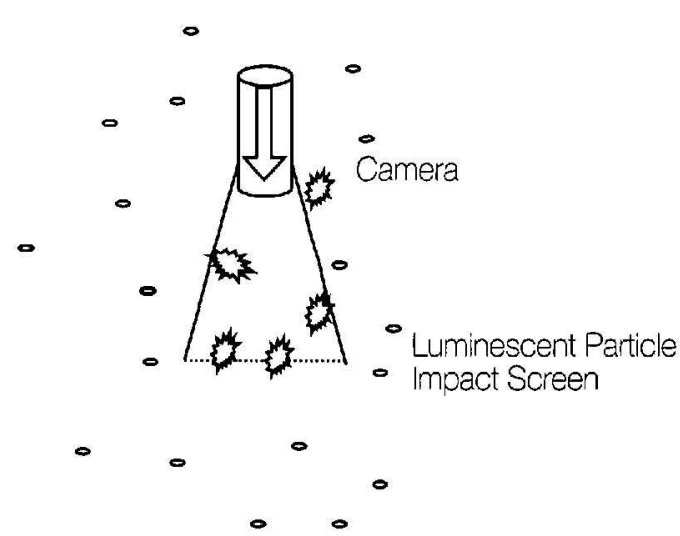

(a)

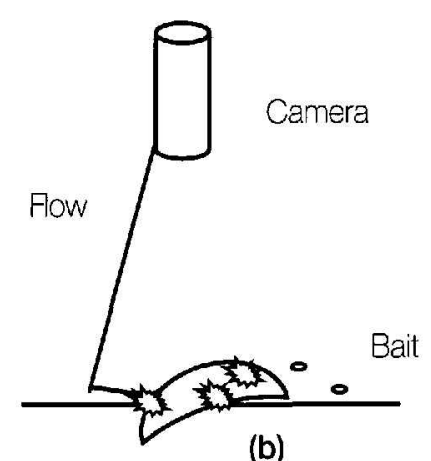

(b) 


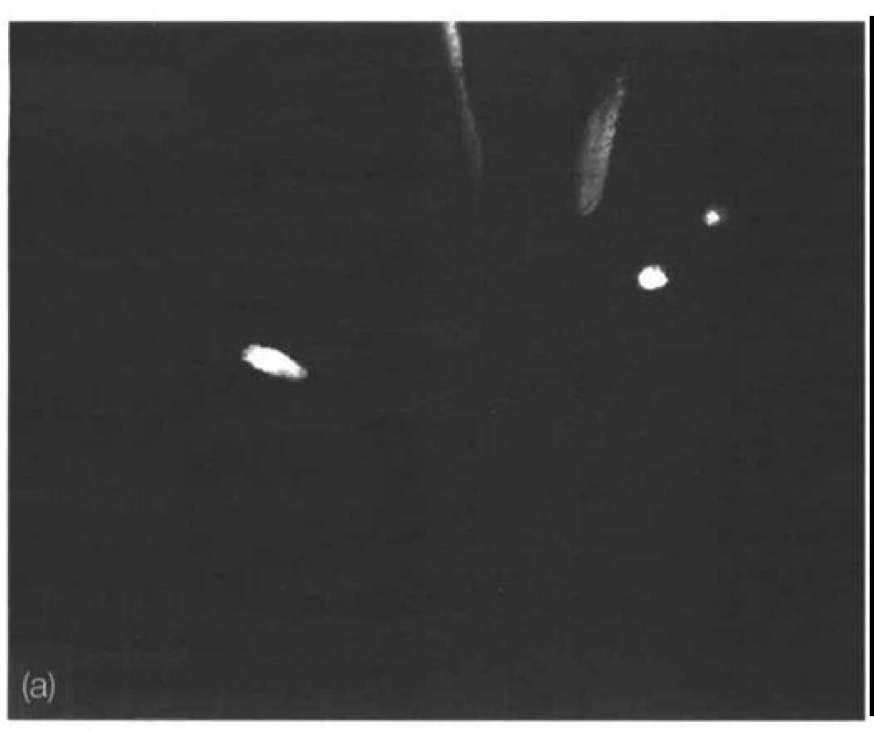

Fig 8: Examples of luminescent recording from the ISIT lander; (a) Bathypelagic luminescent events generated by impacting the mesh screen as the ISIT lander free-

falls through the water column; (b) Spontaneous sea floor luminescent events observed moving across a bait

As the lander free-fell through the water column any bioluminescent particles impacting the screen luminesced in view of the camera. This enabled a vertical profile of bioluminescent particles to be measured from the surface to the abyssal sea floor.

For sea floor experiments, the mesh screen was removed and replaced with bait situated at the focal length of the downward looking ISIT camera (Fig 7b). Once on the sea floor, any spontaneous bioluminescent activity caused by animal activity was observed. Recording took place in time-lapse segments spread over the period of the deployment. Towards the end of cach segment a LED and then a light were illuminated for calibration and identification purposes.

The ISIT lander was controlled by a 68000 base microprocessor (Onset Computer Corp) that took inputs from an onboard real-time clock and control program to schedule events with respect to system power-up time. Although the operating system software was written in $\mathrm{C}$, to enable ease of use and flexibility of system operation a higher level ISIT lander instruction code (LIS) was created. The LIS program was in the form of a text file situated on removable flash card media that the microprocessor would parse directly after power up. Any illegal commands would result in the system not issuing an 'all clear' signal (10 flashes of the lamp) indicating to the user that the lander should not be deployed until the problem had been resolved. Commands could be scheduled to a resolution of $1 \mathrm{~s}$.

Composite video from the ISIT camera from timelapse recording segments was fed to a miniature digital video recorder (Sony Walkman GV-D300) contained within the controller housing aboard the lander. A current meter with onboard CTD instruments enabled
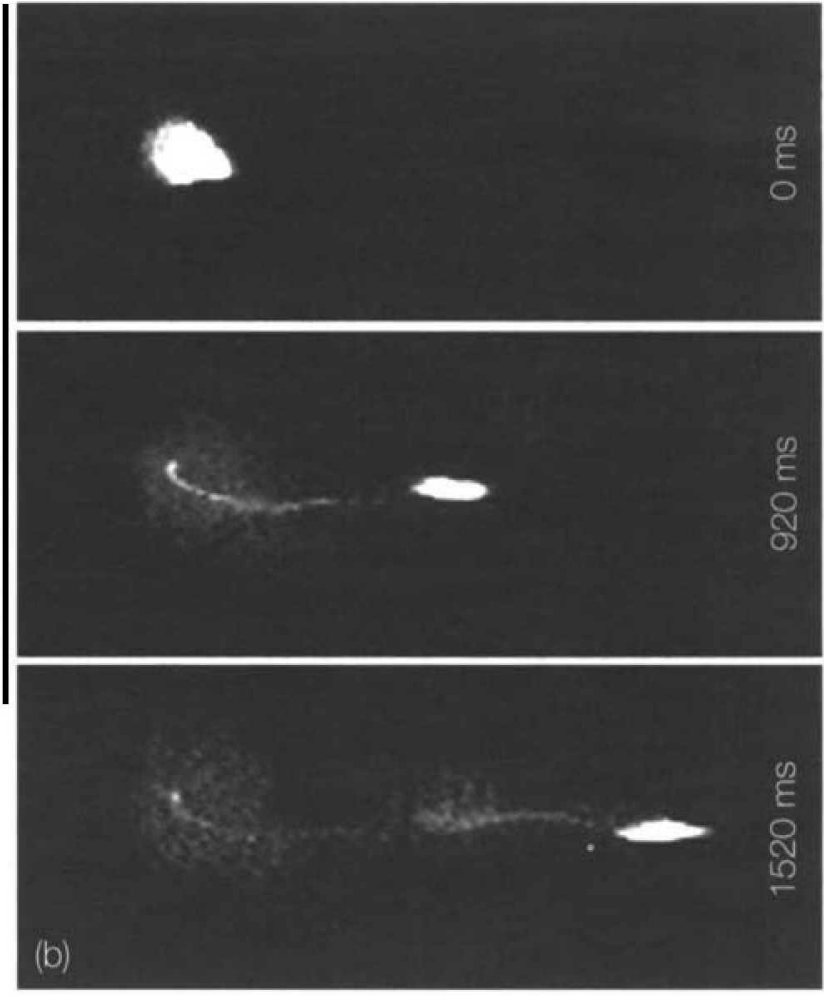

video recordings to be taken against measurements of the local environmental conditions.

Fig 8 shows typical examples of luminescent events occurring during free-fall (Fig 8a), and on the sca floor at bait (Fig 8b). The bathypelagic cxperiments have given insights into the vertical profile of bioluminescence in the water column, and its changes between seasons. Bioluminescence observed at bait on the sea floor has suggested the presence of communication not previously thought to exist on the deep-ocean floor.

\section{The FRESP respirometry lander}

Deep-sea fishes are characterised by high water content, ${ }^{19,20}$ low metabolic enzyme activity ${ }^{21}$ small hearts, ${ }^{22}$ and other adaptations that are indicative of low metabolic rates. However, there is no consistent relationship between metabolism and depth for all animal groups (eg, ${ }^{23,24,25}$ ). Conventional laboratory studies of decp-sca fish are not possible as these fish are typically killed during recovery to the surface due to temperature change and decompression. The FRESP (Fish RESPirometry) lander was conceived to enable in-situ respirometry at depths to $6000 \mathrm{~m} .{ }^{26}$

The FRESP lander consisted of a watertight trap in view of a downward looking digital video camcra. Initially, the trap was held above a base plate containing $5 \mathrm{~kg}$ of mackerel bait (Fig 9). The positioning of the trap allowed fish attracted to the bait to be undisturbed by any structures relating to the trap design. The bchaviour of deep-sea fish was sufficiently understood to allow the trap to be released by time release under the command of a central controller. Once released, the trap fell under its own weight to seal to a base plate trapping any fish still at the bait. 
Fig 9: The FRESP Respirometry Lander; (a) Internally recording digital video camera; (b) acoustic releases; (c) Lights; (d) respirometry chamber in its raised position; (e) repirometry chamber base plate (bait located in the centre of the plate); (f) oxygen sensor and pump; (g) controller and data logging; (h) battery

During the trapping process the digital video camcra was recording to assess the behaviour of the fish and trapping system. Once the fish were trapped, an impeller constantly circulated the water within the chamber. At periodic intervals, the oxygen level of the chamber water was measured with a Beckman-type polarographic oxygen electrode (Sea Bird Electronics Inc SBE 23B). Water was drawn from the chamber at approximately $50 \mathrm{ml}^{-1}$ by a pump (Sea Bird Electronics Inc SBE 5T) across the sensor and returned to the chamber. A customised, pressure compensated threeway valve alternated flow across the sensor between the chamber water for measurement and external ambient water for sensor calibration. Samples were taken at 40 min intervals and consisted of 3 min of ambient water sampling to allow repolarisation of the electrode membrane, 3 min sampling from the chamber and a further 3 min of ambient water sampling. Typically, the experiment duration was three days.

A central controller, similar in design to the ISIT lander system, controlled all lander sub-systems except the acoustic releases. Each subsystem could be independently operated at specified times and durations through a text-based program that was configured by the user prior to deployment. Data from oxygen measurements were stored on-board the controller's flash card memory, which was removed and downloaded on recovery of the lander.

The background oxygen consumption due to the bait was measured during control experiments. The FRESP lander was deployed with the respirometer chamber closed and oxygen levels recorded, ie, no fish in the chamber. The intent was to subtract these levels from any measurements with fish in the chamber. However these levels were found to be very low and within the noise level of the measurements.

Data from trapping the fish Coryphaenoides armatus at $4000 \mathrm{~m}$ showed a low metabolic rate $\left(3.6 \pm 0.2 \mathrm{mLh}^{-1} \mathrm{~kg}^{-1}\right)$ in this species when compared with other gadid species. ${ }^{26}$ During use in the deep ocean other species such as amphipods and bacteria were caught in the trap along with the target species. However, analysis showed that oxygen consumption of the bi-catch species was within the range of the background noise.

\section{The long-term DOBO lander}

The deep sea has historically been perceived as a stable environment receiving a constant rain of organic mat-

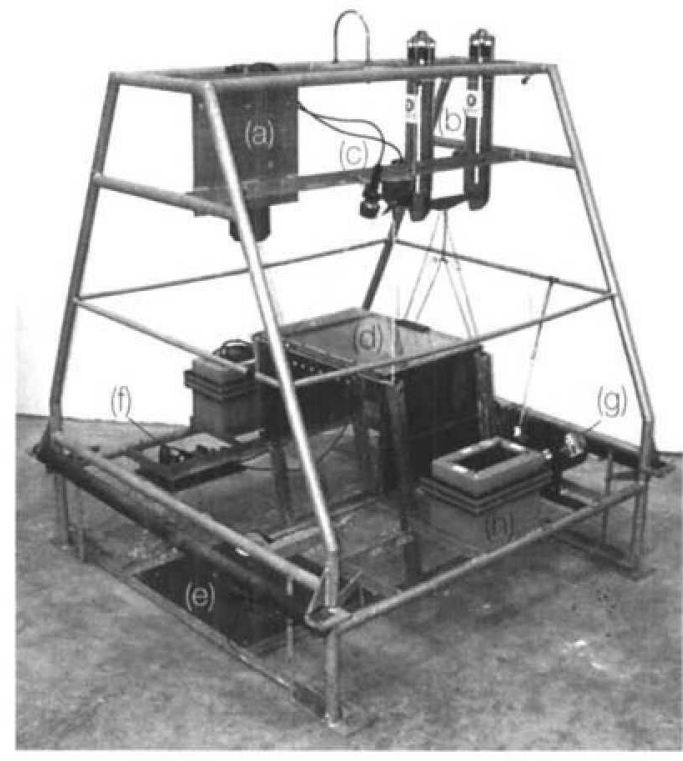

ter from the surface layers above. ${ }^{27}$ The discovery of a seasonal pattern to this input has altered this perception. ${ }^{28}$ Cyclical periodicity in reproductive strategies, and seasonal patterns of growth and activity among the deep-sea fauna further indicate that these animals are responsive to, perhaps dependent on, time signals in their environment, ${ }^{20,30,31}$ yet the temporal and spatial variability of these influences are still poorly understood. The DOBO lander (Decp Ocean Benthic Observer) was designed to monitor deep-ocean physical parameters and observe the biological response.

The DOBO lander was designed to operate for periods exceeding six months. In addition, it was equipped with an ADCP (RDI, USA) and a current meter (FSI, USA) for background current measurements and a large capacity $35 \mathrm{~mm}$ stills camera to observe animals attracted to bait. Initially, the DOBO was deployed with a large food fall (porpoise carcass). However, data are difficult to analyse against the background of steadily detcriorating bait. Therefore, to investigate changes in the frequency, behaviour, size and number of fish visitors to the bait over the winter and spring months, a periodic bait release system was developed. This consisted of an amino acid solution that was designed to mimic fish bait. A proportion of the solution was pumped into a sponge in-view of the camera and under the control of a very low power controller. The sponge allowed the amino acid solution to slowly generate an odour plume rather than be washed away in the ambient current. The very low power controller was a 68000 base microprocessor (Onset Computer Corp, USA) with controlling software that was able to shut down non-essential microprocessor systems and to slow down the system clock to conserve power during sleep periods between obscrvations. The low power control software was transparent to the user, who used a text-based language similar to that described above to bias photography around bait releases. 


\subsection{Conclusion}

Landers provide a cost effective and efficient means of transporting experiments to the deep-ocean floor. For experiments lasting $8 \mathrm{~h}$ or longer landers can also be shown to provide a more efficient use of available ship time than wire-deployed systems, providing the ship has other useful work to do. However, there is always a greater risk of loss than with a wire gear. Fairly sophisticated experiments can be carried out using landers, but robust manufacture and design are of the utmost importance, particularly with long-term landers where instrument failure or controller software crashes would not be discovered until after recovery.

With the advent of sophisticated oceanographic tools such as deepwater ROVs, manned submersibles, and AUVs, a lander retains a niche in sea floor experimentation where:

- measurements or observations are required over very long periods. In particular with the recent interest in cabled networks where sensor technology is still not mature enough for semi-permanent deployments of 10 years or more, ${ }^{32}$ a lander system attached to a cabled network could provide a useful transport tool that could be connected to the sea floor network yet still be recovered to the surface for sensor servicing

- investigating phenomena that occur infrequently or sporadically. Here it would be difficult to justify funding for long duration ROV or AUV support, but a lander used off a vessel with other useful work to do would provide a cost effective solution. An example of this type of experiment is the investigation of spontaneous bioluminescent events with the ISIT lander

- use on ships of opportunity is possible where those ships do not have suitable warp for deep-ocean deployment or the DP and other systems necessary for ROV and submersible operations

- relatively undistributed observation or sampling is required (ROV and manned submersible thrusters can disturb sea floor sediment and communities).

\section{References}

1. Priede, IG. (1983). Use of satellites in marine biology. Experimental Biology at Sea. Eds A MacDonald and IG Pricde (New York: Academic) pp 3-50.

2. Merrett, NR and Hacdrich. (1997). Deep-sea demersal fish and fishes. Chapman and Hall, London.

3. Gilchrist, I, MacDonald, AG and Priede, IG. (1983). Divers, submersibles and unmanned vehicles. Experimental Biology at Sca, Eds AG Macdonald and IG Priede. Academic Press, London.

4. Doolittle, D. (2003). The payoff is in the payload: using $A U V_{s}$ in scientific research. Underwater Magazine, Doyle Publishing Co. March/April 2003.

5. Priede, IG. (1999). Autonomous lander instrument plat- forms for oceanographic research (ALIPOR). Final report. EU Mast 3. Contract No MAS3-CT950010.

6. Priede, IG. (1996). RRS Discovery Cruise Report 222 (leg A). 27 July-26 August 1996.

7. Bett, BJ. (2003). Time-lapse photography in the deep sea. Underwater Technology 25 No 3, pp 121-127.

8. Mitson, RB and Storeton-West. (1971). A transponding acoustic fish tag. Radio \& Electronic Engincer 41 483-489.

9. Bagley, PM. (1992). A code activated transponder for individual identification and tracking of deep-sea fish. Wildlife Telemetry, Eds Priede and Swift. Ellis Horward, Chichester, England.

10. Bagley, PM, Bradley, S, Priede, IG and Gray, P. (1999). Measurement of fish movements at depths to $6000 \mathrm{~m}$ using a deep-ocean lander incorporating. a short base-line sonar utilising miniature code-activated transponder technology. Meas. Sci Technol 10 1214-1221.

11.Bagley, PM and Priede, IG. (1997). An autonomous free-fall acoustic tracking system for investigation of fish behaviour at abyssal depths. Aquat. Living. Resour. 10 67-74.

12. Bailey, DM, Bagley, PM, Jamicson, AJ, Collins, MA and Priede, IG. (2003). In-situ investigation of burst swimming and muscle performance in the deep-sea fish Antimora rostrata. (Gunther, 1878). Journal of Experimental Marine Biology and Ecology 285286, 295-311.

13. Cowx, IG. (Ed) (1990). Developments in electric fishing. Fishing News Books, Blackwell Scientific Publications. Oxford. England.

14. Cowx, IG and Lamarque, P. (1990). Fishing with electricity: Applications in freshwater fisheries management. Fishing News Books, Blackwell Scientific Publications. Oxford. England.

15.James, RS and Johnston, IA. (1998). Scaling of muscle performance during escape responses in the fish Myoxocephalus scorpius L. Journal of Experimental Biology 201 913-923.

16. Johnson, TP and Johnston, IA. (1991). Power output of fish muscle fibres performing oscillatory work: effects of acute and seasonal temperature change. Journal of Experimental Biology 157 409-423.

17. Priede, IG, Williams, LM, Wagner, HJ, Thom, A, Brierley, I, Collins, MA, Collin, SP, Merrett, NR and Yau, C. (1999). Implications of the visual system in regulation of activity cycles in the absence of solar light: $2-\left[^{25} I\right]$ iodomelatonin binding sites and melatonin receptor gene expression in the brains of demersal deep-sea gadiform fishes. Proceedings of the Royal Society. Series B 266: 2295-2302.

18. Herring, PJ. (1990). Bioluminescent communication in the sea. Light \& Lifc in the Sca (Ed PJ Hcrring et al), pp 245-264. Cambridge.

19. Childress, JJ and Nygaard, MH. (1973). The chemical composition of midwater fishes as a function of depth of 
occurrence off southern California. Deep-Sea Research 20, 1093-1109.

20. Childress, JJ, Price, MH, Favuzzi, J and Cowles, D. (1990). Chemical-composition of midwater fishes as a function of depth occurrence off the Hawaiian-islands - food availability as a selective factor. Marine Biology 105, 235-246.

21. Childress, JJ and Somero, GN. (1979). Depth-related enzyme activities in muscle, brain, and heart of deep-living pelagic marine teleosts. Marine Biology 52, 272-283.

22. Greer-Walker, M, Santer, RM, Benjamin, M and Norman, D. (1985). Heart structure of some deep-sea fish (Teleostei: Macrouridae). Journal of Zoology 205, 75-89.

23. Childress, JJ and Thuesen, EV. (1993). Effects of hydrostatic pressure on metabolic rates of six species of deepsea gelatinous zooplankton. Limnology \& Oceanography 38, 665-670.

24.Cowles, DL, Childress, JJ and Wells, ME. (1991). Metabolic rates of midwater crustaceans as a function of depth occurrence off the Hawaiian islands - food availability as a selective factor. Marine Biology 110 , 75-83.
25. Seibel, BA and Childress, JJ. (2000). Metabolism of benthic octopods (Cephalopoda) as a function of habital depth and oxygen concentration. Deep-Sea Research I 47, 1247-1260.

26. Bailey, DM, Jamieson, AJ, Bagley, PM, Collins, MA and Priede, IG. (2002). Measurement of in-situ oxygen consumption of deep-sea fish using an autonomous lander vehicle. Deep-Sea Research I, 868, 1-11.

27. Sanders, HL. (1968). Marine benthic diversity: a comparative study. Am. Nat 102, 243-282.

28. Billet, DSM, Lampitt, RS, Rice, AL and Mantoura, RFC. (1983). Seasonal sedimentation of phytoplankton to the deep-sea benthos. Nature 302, 520-522.

29. Palmer, JD. (2002). The living clock: The orchestrator of biological rhythms. Oxford University Press.

30. George, RY and Menzies, RJ. (1967). Indication of cyclic reproductive activity in abyssal organisms, Nature, 215, p 878.

31. Tyler, PA. (1988). Seasonality in the deep sea. Oceanogr. Mar Biol. Annu. Rev. 26 pp 227-258.

32. National Rescarch Council (2000). Illuminating the hidden planet: the future of seafloor observatory science. National Academic Press, USA. 